\title{
Type I interferon elevates co-regulatory receptor expression on CMV- and EBV-specific CD8 $T$ cells in chronic hepatitis $C$
}

\section{OPEN ACCESS}

Edited by:

Rene De Waal Malefyt, Merck Research Laboratories, USA

Reviewed by: Koji Yasutomo,

University of Tokushima, Japan Vasileios Bekiaris,

Danish Technical University, Denmark

*Correspondence:

Verena Schlaphoff,

Department of Gastroenterology,

Hepatology and Endocrinology,

Hannover Medical School,

Carl-Neuberg-Str. 1, Hannover

30625, Germany

schlaphoff.verena@mh-hannover.de

${ }^{\dagger}$ Markus Cornberg,

Heiner Wedemeyer and Verena

Schlaphoff have contributed equally to this work.

Specialty section:

This article was submitted to T Cell Biology, a section of the journal Frontiers in Immunology

Received: 11 March 2015 Accepted: 15 May 2015

Published: 10 June 2015

Citation:

Owusu Sekyere S, Suneetha PV, Hardtke S, Falk CS, Hengst J,

Manns MP, Cornberg M, Wedemeyer $\mathrm{H}$ and Schlaphoff $\mathrm{V}$ (2015) Type I interferon elevates co-regulatory receptor expression on $C M V$ - and EBV-specific CD8

$T$ cells in chronic hepatitis $C$.

Front. Immunol. 6:270.

doi: 10.3389/fimmu.2015.00270

\section{Solomon Owusu Sekyere ${ }^{1}$, Pothakamuri Venkata Suneetha ${ }^{1}$, Svenja Hardtke ${ }^{1}$, Christine Susanne Falk ${ }^{2,3}$, Julia Hengst ${ }^{1}$, Michael Peter Manns ${ }^{1,2}$, Markus Cornberg ${ }^{1,2+}$, Heiner Wedemeyer ${ }^{1,2 t}$ and Verena Schlaphoff ${ }^{1 * t}$}

\footnotetext{
${ }^{1}$ Department of Gastroenterology, Hepatology and Endocrinology, Hannover Medical School, Hannover, Germany, ${ }^{2}$ TTUHepatitis, TTU-IICH, German Center for Infectious Diseases (DZIF), Hannover-Braunschweig, Germany, ${ }^{3}$ Institute of Transplantation Immunology (IFB-TX), Hannover Medical School, Hannover, Germany
}

Hepatitis $\mathrm{C}$ virus $(\mathrm{HCV}$ ) readily sets up persistence in a large fraction of infected hosts. Mounting epidemiological and immunological evidence suggest that HCV's persistence could influence immune responses toward unrelated pathogens and vaccines. Nonetheless, the fundamental contribution of the inflammatory milieu during persistent HCV infection in impacting immune cells specific for common pathogens such as CMV and EBV has not been fully studied. As the co-regulatory receptors PD-1, Tim-3, and 2B4 have all been shown to be vital in regulating $\mathrm{CD}^{+} \mathrm{T}$ cell function, we assessed their expression on CMV/EBV-specific CD8 ${ }^{+} \mathrm{T}$ cells from patients with chronic hepatitis $\mathrm{C}(\mathrm{CHC})$ and healthy controls ex vivo and upon stimulation with virus-specific peptides in vitro. Total and CMV/EBV-specific CD8 ${ }^{+}$T cells expressing PD-1, Tim-3, and 2B4 were highly enriched in patients with $\mathrm{CHC}$ compared to healthy individuals ex vivo. In vitro peptide stimulation further potentiated the differential co-regulatory receptor expression of PD-1, Tim-3, and 2B4, which then culminated in an enhanced functionality of CMV/EBV-specific CD8 ${ }^{+}$ $\mathrm{T}$ cells in $\mathrm{CHC}$ patients. Comprehensively analyzing plasma cytokines between the two cohorts, we observed that not only was IFN $\alpha$-2a dominant among 21 other inflammatory mediators elevated in $\mathrm{CHC}$ patients but it also correlated with PD-1 and Tim-3 expressions ex vivo. Importantly, IFN $\alpha$-2a further caused upregulation of these markers upon in vitro peptide stimulation. Finally, we could prospectively study patients receiving novel IFN-free antiviral therapy. Here, we observed that treatment-induced clearance of $\mathrm{HCV}$ resulted in a partial reversion of the phenotype of CMV/EBV-specific CD8 ${ }^{+} \mathrm{T}$ cells in patients with $\mathrm{CHC}$. These data reveal an alteration of the plasma concentrations of IFN $\alpha$-2a together with other inflammatory mediators during $\mathrm{CHC}$, which appeared to pervasively influence co-regulatory receptor expression on CMV/EBV-specific CD8 ${ }^{+}$ T cells.

Keywords: hepatitis C, IFN-alpha, cytokines, co-regulation, T cell regulation, PD-1, TIM-3, 2B4 


\section{Introduction}

Chronic diseases caused by various pathogens impact a large proportion of the global population. Recent updated global estimates indicate that persistent infections with hepatitis $\mathrm{C}$ virus (HCV) alone affect about 80 million infected individuals (1). Like for many other viruses, antiviral $\mathrm{T}$ cell responses are particularly critical in limiting persistent infections and conferring lifelong protective immunity to viral re-exposures (2). In the majority of patients with chronic hepatitis $\mathrm{C}(\mathrm{CHC})$, however, viral clearance often fails as a result of an exhausted cytotoxic $\mathrm{T}$ cell response mediated by several co-regulatory receptors such as PD-1, CTLA-4, Tim-3, and 2B4 (3). Despite being functionally exhausted, T cell responses during persistent $\mathrm{HCV}$ infection remain strong enough to cause ongoing hepatocyte destruction (4). In the wake of the tissue pathology that ensues, several intrahepatic immune-modulatory cytokines (5) and chemokines (6) are induced.

Besides causing chronic intrahepatic inflammation and tissue destruction, persistent HCV infection has been associated with a plethora of extra-hepatic diseases, including autoimmune

TABLE 1 | Clinical characteristics of study cohorts.

\begin{tabular}{|c|c|c|c|}
\hline Parameter & $\begin{array}{l}\text { Chronic HCV } \\
\text { (no therapy) }\end{array}$ & $\begin{array}{c}\text { Chronic HCV } \\
\text { (sofosbuvir-treated) }\end{array}$ & Healthy \\
\hline Time point & & Baseline & \\
\hline Number of subjects $(n)$ & 69 & 7 & 90 \\
\hline $\begin{array}{l}\text { Number of HLA-A2 } \\
\text { positive patients }\end{array}$ & 61 & 7 & 67 \\
\hline Male sex - no. (\%) & $36(52)$ & $3(43)$ & N/A \\
\hline \multicolumn{4}{|l|}{ Age (years) } \\
\hline $\begin{array}{l}\text { Median } \\
\text { Range }\end{array}$ & $\begin{array}{c}49 \\
22-80\end{array}$ & $\begin{array}{c}57 \\
53-67\end{array}$ & $\begin{array}{l}\text { N/A } \\
\text { N/A }\end{array}$ \\
\hline \multicolumn{4}{|l|}{ HCV RNA - (IU/ml) } \\
\hline $\begin{array}{l}\text { Median } \\
\text { Range } \\
\geq 8 \times 105 \mathrm{lU} / \mathrm{ml}-\text { no./ } \\
\text { total no. (\%) }\end{array}$ & $\begin{array}{c}1.2 \times 10^{6} \\
8.6 \times 10^{4}-9.8 \times 10^{6} \\
39 / 63(62)\end{array}$ & $\begin{array}{c}730,000 \\
1.8 \times 10^{5}-1.1 \times 10^{7} \\
3 / 7(43)\end{array}$ & $\begin{array}{l}\text { N/A } \\
\text { N/A } \\
\text { N/A }\end{array}$ \\
\hline Unknown & 6/69 (9) & N/A & N/A \\
\hline Undetectable & $6 / 69(9)$ & N/A & $\mathrm{N} / \mathrm{A}$ \\
\hline \multicolumn{4}{|l|}{$\begin{array}{l}\text { Alanine } \\
\text { aminotransferase - (U/l) }\end{array}$} \\
\hline Median & 71.5 & 67 & $\mathrm{~N} / \mathrm{A}$ \\
\hline Range & $10-311$ & $28-224$ & N/A \\
\hline $\begin{array}{l}\text { Above median - no./ } \\
\text { total no. (\%) }\end{array}$ & $34 / 68$ (50) & $3 / 7(43)$ & N/A \\
\hline Unknown & $1 / 69(1.5)$ & N/A & N/A \\
\hline \multicolumn{4}{|l|}{$\begin{array}{l}\text { Aspartate } \\
\text { aminotransferase - (U/I) }\end{array}$} \\
\hline Median & 54.5 & 54 & N/A \\
\hline Range & $22-279$ & $27-118$ & N/A \\
\hline $\begin{array}{l}\text { Above median - no./ } \\
\text { total no. (\%) }\end{array}$ & $34 / 68(50)$ & $3 / 7(43)$ & N/A \\
\hline Unknown & $1 / 69(1.5)$ & $\mathrm{N} / \mathrm{A}$ & $\mathrm{N} / \mathrm{A}$ \\
\hline \multicolumn{4}{|l|}{ HCV genotype - no. (\%) } \\
\hline 1 & $50(82)$ & $0(0)$ & N/A \\
\hline 2 & $2(3)$ & $1(14)$ & N/A \\
\hline 3 & $9(15)$ & $5(72)$ & N/A \\
\hline 5 & $0(0)$ & $1(14)$ & N/A \\
\hline Not determined & $8(12)$ & $0(0)$ & N/A \\
\hline
\end{tabular}

N/A, not applicable. perturbations, lymphoproliferative disorders, diabetes, as well as neurological complications (7). Accumulating epidemiological evidence further suggests that persistent HCV infection might impact the incidence as well as immune responses toward unrelated pathogens and vaccines. Particularly, immune responses to vaccines against hepatitis A $(8,9)$, hepatitis B $(10,11)$, and influenza A (12) viruses are reduced in subjects with CHC. Similar to what pertains in HCV-related neuropathy (13), it is conceivable that the inflammatory mediators induced during persistent $\mathrm{HCV}$ infection contribute to influencing immune responses to other microbes. Indeed, an altered cytokine milieu was implicated in the substantial skewing of $\mathrm{T}$ cell differentiation, proliferation, and effector function observed in different settings of persistent virus and parasitic infections in both animal models and human diseases $(11,14,15)$. Importantly, the impact of persistent infections transcends those that are pathogen specific as they may also have a global influence on the phenotype of the bulk $\mathrm{T}$ cell population (16). In spite of all these strides, the contribution of the inflammatory milieu during persistent $\mathrm{HCV}$ infection in impacting the phenotype and functional attributes of antigen-specific CD8 ${ }^{+} \mathrm{T}$ cell responses toward common pathogens such as CMV and EBV is not yet fully understood. So far, the limited data available on this subject are conflicting. While some reports suggest that persistent $\mathrm{HCV}$ infection may cause pervasive T cell intrinsic changes, which influence the phenotype of circulating $\mathrm{CMV}$-specific $\mathrm{CD}^{+} \mathrm{T}$ cells $(16,17)$, others show otherwise (18).

In essence, we here evaluated whether persistent $\mathrm{HCV}$ infection may influence the phenotype and functionality of CMV/EBVspecific $\mathrm{CD}^{+} \mathrm{T}$ cells through distinct co-regulatory receptor molecules. Our results reveal a profound $\mathrm{HCV}$-induced alteration of various inflammatory mediators, which appeared to influence the frequency, phenotype, and in vitro functionality of both total and virus-specific CD8 ${ }^{+} \mathrm{T}$ cells of CMV and EBV. Importantly, these effects normalized upon treatment-induced HCV clearance.

\section{Materials and Methods}

\section{Study Subjects}

A total of 154 subjects participated in this study. This included 76 patients with $\mathrm{CHC}$ recruited from the liver outpatient clinic and 78 healthy individuals comprising blood donors from the internal blood donation center or healthy employees of the Hannover Medical School undergoing routine check-ups. All patients were anti-HIV and HBsAg negative and had no evidence of active CMV or EBV disease. Of the patients with $\mathrm{CHC}, 69$ had not received any prior antiviral treatment, while 7 had received IFN-free antiviral therapy with sofosbuvir + ribavirin for 12-24 weeks. Untreated CHC patients had a compensated liver disease (13\% cirrhosis) and a median viral load, ALT and AST of $1.2 \times 10^{6} \mathrm{IU} / \mathrm{ml}, 71.5$, and $54.5 \mathrm{U} / \mathrm{l}$, respectively. The seven patients who had received sofosbuvir therapy had cleared the virus at end of therapy, developed a sustained virologic response, and were non-cirrhotic and normalized ALT and AST levels. For these patients, blood samples were collected at baseline (i.e., before therapy) and 12 weeks after end of therapy (FuW12). Patient cohorts and characteristics are summarized in Table 1. The calculation of the absolute cell numbers of $\mathrm{CMV}$ - and $\mathrm{EBV}$-specific $\mathrm{CD}^{+}{ }^{+} \mathrm{T}$ cells from patients 
with sofosbuvir treatment was performed using the frequencies of multimer-positive $\mathrm{CD}^{+} \mathrm{T}$ cells referring to the lymphocyte gate (frequency of lymphocytes) obtained by FACS analysis. The total lymphocyte counts obtained from clinical hematological diagnostics were used to calculate the absolute cell counts together with the FACS frequencies obtained.

\section{Isolation and Storage of PBMC and Blood Plasma Samples}

Peripheral blood mononuclear cells (PBMCs) were isolated from fresh blood samples using standard Ficoll density gradient centrifugation. Cells were cryopreserved in freezing medium consisting of 30\% RPMI-1640 medium (Invitrogen, Karlsruhe, Germany), 60\% fetal bovine serum (PAA, Pasching, Austria), and $10 \%$ DMSO (Sigma-Aldrich, Munich, Germany). Blood plasma sample collection was done from CPDA-treated blood samples and stored at $-20^{\circ} \mathrm{C}$.

\section{Peptides, HLA Class I Multimers, and Recombinant Proteins}

Antigenic HLA-A ${ }^{\star} 0201$ restricted CMV-specific pp65495-504 (NLVPMVATV) and EBV-specific BMLF1 $1_{259-267}$ (GLCTLVAML) peptides were purchased from ProImmune Ltd. (Oxford, UK). Peptides were dissolved in endotoxin-free DMSO (Sigma-Aldrich, Munich, Germany) and had a purity of $>98 \%$. Corresponding PE-labeled MHC class I CMV tetramer as well as EBV Dextramer were obtained from Beckman Coulter Inc. (Fullerton, CA, USA) and Immudex (Copenhagen, Denmark), respectively. For in vitro stimulations, PEG-IFN-alfa-2a (Pegasys; Roche) was used. Additionally, lyophilized recombinant human ICAM-1 and VCAM-1 were obtained from PeproTech Inc. (Rocky Hill, NJ, USA) and reconstituted in $0.1 \%$ bovine serum albumin solution according to the manufacturer's instructions.

\section{Fluorescent Antibodies and Phenotypical Staining}

The following mouse anti-human monoclonal antibodies (MAb) were used: anti-PD1/clone EH12.2H7 (BioLegend Inc., San Diego, CA, USA), anti-2B4/clone C1.7 (Beckman Coulter, Fullerton, CA, USA) as wells as anti-Tim3/clone 344823, and anti-human IFN $\gamma /$ clone 25723 (R\&D Systems, Minneapolis, MN, USA). AntiCD14/clone M5E2, anti-CD19/clone 5J25C1, anti-CD56/clone B159, anti-CD107b/clone H4B4, anti-TNF/clone MAb11, anti$\mathrm{CD} 8 /$ clone SK1, and mouse IgG isotype controls were all obtained from BD Pharmingen (Becton Dickinson, Heidelberg, Germany). Tetramer and antibody stainings were performed as detailed previously (19). Cells were acquired using a BD FACSCanto II flow cytometer (Becton Dickinson, Heidelberg, Germany) and analyzed with FlowJo Software (TreeStar Inc., San Diego, CA, USA). A multimer-specific $\mathrm{CD}^{+} \mathrm{T}$ cell population was considered detectable if the frequency was at least $0.1 \%$ of total CD8 ${ }^{+} \mathrm{T}$ cells. Exclusion of unspecific events was done using a dump channel $\left(\mathrm{CD} 14^{+} \mathrm{CD} 19^{+} \mathrm{CD}^{+} 6^{+}\right)$. Respective FMO controls were included to enable gating of cell populations.

\section{In vitro Cellular Stimulation}

Peripheral blood mononuclear cells were thawed and plated at $3-4 \times 10^{5}$ cells/well in 96-well $U$-bottomed plates (Sarstedt
GmbH, Nümbrecht, Germany). Respective CMV- or EBVspecific peptides at optimal concentrations (CMV: $1 \mu \mathrm{g} / \mathrm{ml}$, EBV: $0.5 \mu \mathrm{g} / \mathrm{ml}$ ) were added to stimulate the cells. Conditions of unstimulated cells were included as negative controls. All cultures were kept in AB-Medium (RPMI-1640), 10\% heatinactivated human $\mathrm{AB}$ serum (PAN Biotech $\mathrm{GmbH}$, Germany), $1 \%$ non-essential amino acids, $1 \%$ sodium pyruvate, $1 \%$ penicillin/streptomycin, $0.5 \%$ HEPES buffer (GIBCO), and supplemented with $5 \mathrm{IU} / \mathrm{ml}$ fresh human recombinant IL-2 (Invitrogen, Karlsruhe, Germany) at day 3 and 7 during culture. For the cytokine/chemokine stimulation assay, PBMCs were stimulated with 10,100 , or $1000 \mathrm{ng} / \mathrm{ml}$ of ICAM-1, VCAM-1, or IFN $\alpha-2$ a in the presence or absence of virus-specific peptides. In all cases, cells were incubated at $37^{\circ} \mathrm{C}$ and $5 \% \mathrm{CO}_{2}$ for 10 days.

\section{Intracellular Cytokine Staining and CD107a Degranulation Assay}

After 10 days in vitro stimulation, PBMCs were resuspended in fresh $\mathrm{AB}$ medium and incubated in the presence of optimal concentrations of virus-specific peptides as described above. Brefeldin A was added after $1 \mathrm{~h}$ and cells incubated for additional $5 \mathrm{~h}$. Surface staining including CD107 was carried out before intracellular staining for TNF and IFN $\gamma$ was performed as described (19).

\section{Quantification of Plasma Cytokines and Chemokines}

The plasma concentrations of 50 cytokines and chemokines in patients with $\mathrm{CHC}$ and healthy controls as well as $\mathrm{CHC}$ patients treated with sofosbuvir were measured using the Luminexbased multiplex technology (Bio-Plex Pro Human Cytokine Panel, Bio-Rad, Hercules, CA, USA). The assay was performed as per the manufacturer's instructions. Briefly, lyophilized cytokine/chemokine standards were resuspended in standard diluents and a series of serial dilutions performed in order to generate standard curves for each cytokine/chemokine. Fifty microliters of the resuspended standard cytokine/chemokine or plasma samples were pipetted and incubated for $30 \mathrm{~min}$ at RT with a mixture of beads having specificity for each cytokine or chemokine. The beads were washed several times with wash buffer. Biotinylated secondary antibody mixture was added and incubated for $30 \mathrm{~min}$ at RT, washed three times, before staining with streptavidin-conjugated R-phycoerythrin (SAPE). Beads were washed three times and resuspended in $125 \mu$ l assay buffer, acquired and analyzed using the BioPlex Manager 6.0 software. Our internal standard operating procedure for data analysis is available upon request.

\section{Statistical Analyses}

Data were analyzed using GraphPad Prism v6.0b (GraphPad software, La Jolla, CA, USA). Quantitative comparisons were performed using parametric or non-parametric Student's $t$-test. $p$ Values of $<0.05$ were considered to be significant $\left({ }^{*} p<0.05\right.$; $\left.{ }^{* *} p<0.01 ;{ }^{* *} p<0.001 ;{ }^{* * *} p<0.0001\right)$. Correlations were calculated using the Pearson correlation coefficient test. Principal component analysis (PCA) was conducted using Qlucore Omics Explorer v3.0 (Qlucore AB, Lund, Sweden). In the PCA model, $t$-test was used to compare two groups. 


\section{Ethics Statement}

Written informed consent was obtained in all cases as part of protocols approved by the local ethics committee of the Hannover Medical School. All investigations conformed to the principles espoused in the Declaration of Helsinki.

\section{Results}

\section{$\mathrm{CD8}^{+} \mathrm{T}$ Cells from Patients with CHC Show Elevated Co-Regulatory Receptor Expression}

In a previous report, we demonstrated that the co-regulatory receptor 2B4 was increased in expression in patients with $\mathrm{CHC}$ compared to healthy individuals (20). To extend this further and investigate how a broader array of co-regulatory receptor expressions are influenced by a persistent $\mathrm{HCV}$ infection, frequencies of total $\mathrm{CD}^{+} \mathrm{T}$ cells expressing PD-1, Tim-3, and 2B4 were assessed in patients with $\mathrm{CHC}$ and healthy controls ex vivo (Figures 1A,B). Patients with $\mathrm{CHC}$ displayed significantly higher frequencies of PD-1-, Tim-3-, and 2B4-expressing $\mathrm{CD}^{+}{ }^{+} \mathrm{T}$ cells compared to healthy controls (Figure 1B). While the frequency of $\mathrm{PD}$-1-expressing $\mathrm{CD}^{+} \mathrm{T}$ cells was 1.70 -fold higher in patients with $\mathrm{CHC}$, that of Tim-3 and 2B4 were 1.65 and 1.49-fold, respectively, higher as compared to healthy donors.
To specifically evaluate the expression patterns of PD-1, Tim3 , and $2 \mathrm{~B} 4$ on antigen-specific $\mathrm{CD} 8^{+} \mathrm{T}$ cells in both cohorts, we focused on CMV and EBV; two common human pathogens with large $\mathrm{CD}^{+} \mathrm{T}$ cell memory pools that are easily detectable ex vivo. Patients with $\mathrm{CHC}$ harbored significantly higher frequencies of $\mathrm{CMV}$ - and $\mathrm{EBV}$-specific CD ${ }^{+} \mathrm{T}$ cells ex vivo in relation to healthy individuals (Figure 1C). In fact, we evaluated the cohort $\mathrm{CHC}$ only as those from the healthy blood donors were unavailable for regulatory reasons. We observed that the frequency of CMV-, but not EBV-specific CD8 ${ }^{+} \mathrm{T}$ cells ex vivo positively correlated with age (data not shown). When the direct ex vivo expression of co-regulatory receptor molecules on CMV-specific $\mathrm{CD}^{+} \mathrm{T}$ cells was compared between patients with $\mathrm{CHC}$ and healthy individuals, we observed that the frequencies of PD-1-, Tim-3-, and 2B4-expressing CMV-specific $\mathrm{CD}^{+}{ }^{+} \mathrm{T}$ cells were significantly increased in the latter (Figure 1D). A similar observation was made for EBV-specific CD8 ${ }^{+} \mathrm{T}$ cells (Figure 1E). Unsurprisingly, the simultaneous co-expression of all three co-regulatory receptors was similarly up-regulated on CMV- and EBV-specific $\mathrm{CD}^{+}{ }^{+} \mathrm{T}$ cells in $\mathrm{CHC}$ patients compared to healthy individuals (data not shown). To further investigate whether age is associated with co-regulatory receptor expression, we used data from patients with $\mathrm{CHC}$. Here, no correlation was observed between co-regulatory receptor expression and age. Patients with $\mathrm{CHC}$

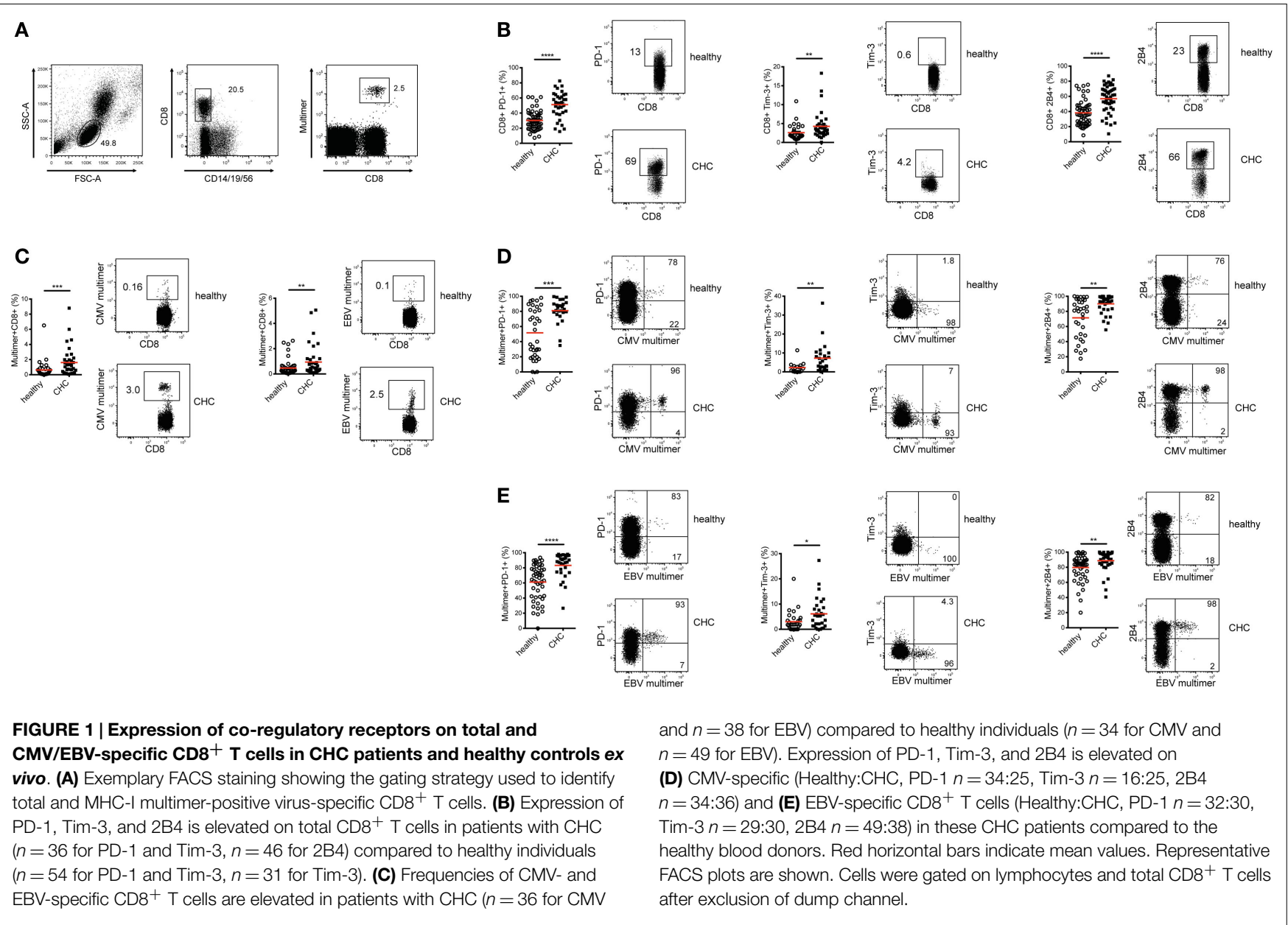


were further categorized into two groups: young ( $<50$ years) and old ( $>50$ years). We still did not observe any differences in coregulatory receptor expression between the two groups (data not shown). In summary, persistent infection with HCV was associated with an altered phenotype of both bulk and CMV- and EBVspecific $\mathrm{CD}^{+} \mathrm{T}$ cells ex vivo with a shift toward co-regulatory receptor upregulation.

\section{In vitro Peptide Stimulation Pronounces the Differential Co-Regulatory Receptor Expression on CMV-/EBV-Specific CD8 ${ }^{+} \mathbf{T}$ Cells in Patients with $\mathrm{CHC}$}

Next, we investigated the dynamics of co-regulatory receptor expression on CMV- and EBV-specific CD8 ${ }^{+} \mathrm{T}$ cells from the two cohorts upon peptide stimulation. PBMCs from randomly selected patients of either cohort were stimulated with virusspecific peptides in vitro for 10 days and subsequently stained with MHC class I multimers. The expression of PD-1, Tim-3, and 2B4 was investigated. Overall, CMV- and EBV-specific CD8 ${ }^{+} \mathrm{T}$ cells showed a similar expression pattern with no significant differences between them as demonstrated in Figure 1. We therefore performed all subsequent analyses with the two cell populations together. Evaluating the two virus-specific $\mathrm{CD} 8^{+} \mathrm{T}$ cell populations together, we observed that the expression of PD-1 and Tim-3 was particularly up-regulated upon peptide stimulation in vitro (Figures 2A,B and 2D,E; Figure S1 in Supplementary Material).
This pattern of response was observed irrespective of the sample source; $\mathrm{CHC}$ patients or healthy blood donors. However, the comparative potentiation of $\mathrm{PD}-1$ and Tim-3 expressions was stronger for $\mathrm{CMV}$ - and EBV-specific $\mathrm{CD}^{+}{ }^{+} \mathrm{T}$ cells in $\mathrm{CHC}$ patients than in healthy individuals (Figures 2A,B and 2D,E). This was evident in the superior fold increases in the CHC patients $(\mathrm{PD}-1=1.82$ fold, Tim-3 $=3.72$-fold) compared to the healthy controls (PD$1=1.36$-fold, Tim-3=3.16-fold). The expression of $2 \mathrm{~B} 4$ was down-regulated but this was only noticeable on CMV- and EBVspecific $\mathrm{CD}^{+}{ }^{+} \mathrm{T}$ cells in healthy individuals (fold decrease $=0.68$ ) compared to patients with $\mathrm{CHC}$ where they remained fairly stable (fold increase $=1.01$; Figures 2C,F; Figure S1 in Supplementary Material). These data indicate that the inflammatory milieu in CHC patients may precondition CMV- and EBVspecific $\mathrm{CD}^{+} \mathrm{T}$ cells to up-regulate co-regulatory receptor expression.

\section{CMV-/EBV-Specific CD8 ${ }^{+}$T Cells from $\mathbf{C H C}$ Patients Display an Elevated Proliferation and Cytokine Production}

In the light of the dichotomy between the dual roles of coregulatory receptor expression in $\mathrm{T}$ cell exhaustion and activation, we next assessed the proliferative, cytokine-producing, and cytotoxic capacities of peptide-stimulated CMV- and EBVspecific $\mathrm{CD}^{+} \mathrm{T}$ cells from the two cohorts. The proliferation of $\mathrm{CMV}$ - and $\mathrm{EBV}$-specific $\mathrm{CD} 8^{+} \mathrm{T}$ cells was significantly
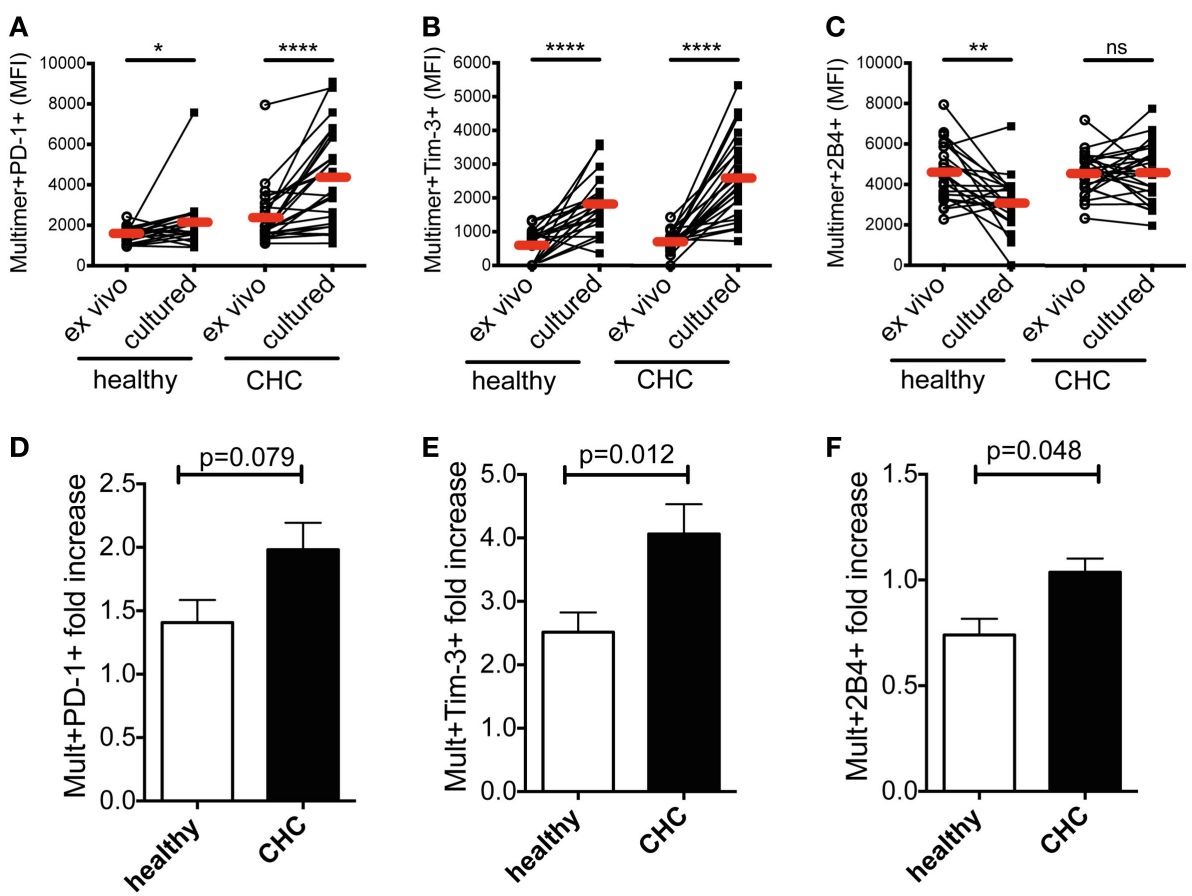

FIGURE 2 | Effect of in vitro peptide stimulation on co-regulatory receptor expression by $\mathrm{CMV}$-/EBV-specific $\mathrm{CDB}^{+}{ }^{+} \mathrm{T}$ cells in patients with $\mathrm{CHC}$ and healthy individuals. A comparison of the mean fluorescence intensities (MFI) of (A) PD-1, (B) Tim-3, and (C) 2B4 expressions on CMV-/EBV-specific CD8 ${ }^{+}$T cells in healthy individuals ( $n=12$ for $\mathrm{CMV} ; n=10$ for EBV) and patients with $\mathrm{CHC}(n=12$ for CMV, $n=14$ for EBV) revealed a stronger increase of expression in $\mathrm{CHC}$ patients upon peptide stimulation in vitro. Indicated are individual values of co-regulatory receptor expression ex vivo and upon culture in vitro. Red horizontal bars indicate mean values. The increase of expression was also revealed by comparing the fold increase of expression of (D) PD-1, (E) Tim-3, and (F) 2B4 upon in vitro peptide stimulation in relation to the ex vivo expression. $p$-Values are indicated. Cells were gated on lymphocytes and total $\mathrm{CD}^{+}{ }^{+} \mathrm{T}$ cells after exclusion of dump channel. 
enhanced in patients with CHC compared to healthy individuals (Figures 3A,B; Figures S2A and S3A in Supplementary Material). This was evident in the 2.23-fold higher expansion observed in $\mathrm{CHC}$ patients (mean fold increase $=49.78$ ) in relation to that of healthy individuals (mean fold increase $=22.35$ ). Similarly, the mean fold increases of IFN $\gamma$ and TNF production as well as $\mathrm{CD} 107 \mathrm{a} / \mathrm{b}$ expression (a surrogate marker for cytotoxicity) were all stronger in patients with $\mathrm{CHC}$ (37.54, 21.36, and 35.81-fold, respectively) compared to healthy controls $(9.49,4.16$, and 2.02fold, respectively) (Figures 3C-E; Figures S2B-D, S3B-D, and S4 in Supplementary Material). This suggests that the stronger induction of co-regulatory receptor expression by CMV- and EBV-specific $\mathrm{CD}^{+} \mathrm{T}$ cells upon in vitro peptide stimulation may culminate in an enhanced proliferation and functional responses rather than attenuating them.

This observation of an enhanced co-regulatory receptor expression on $\mathrm{CD}^{+} \mathrm{T}$ cells and their nevertheless strong functional capacity is contrary to the often described and accepted inhibitory effect of PD-1 and Tim-3 and partially also 2B4. Indeed, to show that the co-regulatory receptor-positive cells might nevertheless effectively proliferate, we grouped the samples of healthy and $\mathrm{CHC}$ individuals according to their ex vivo frequencies of expression of PD-1, Tim-3, and 2B4 into high and low groups. Here, all these groups showed a similar proliferation of CMV- and EBV-specific $\mathrm{CD}^{+} \mathrm{T}$ cells (data not shown), no differences in proliferative responses in correlation to the expression of these co-regulatory receptors were apparent in healthy individuals or $\mathrm{CHC}$ patients.

\section{Plasma Cytokine Patterns Differ Between CHC Patients and Healthy Individuals and Correlate with Expression of Co-Regulatory Receptor Expression}

The foregoing findings prompted us to investigate the possible mechanism behind the altered phenotype and function of $\mathrm{CD} 8^{+}$ $\mathrm{T}$ cells in persistent HCV infection as observed. As cytokines and chemokines produced during chronic inflammation in patients with $\mathrm{CHC}$ may substantially influence immune cells, we aimed to investigate their possible contribution. Thus, we quantified several cytokines and chemokines $(n=50)$ in the plasma of patients with $\mathrm{CHC}$ and healthy individuals using a multiplex bead assay. Using PCA, the differential concentrations of different cytokines and chemokines in CHC patients and healthy individuals resulted in a distinct clusterization of members of each cohort (Figure 4A). Particularly, inflammatory mediators and proteins, such as IFN $\alpha 2$, IL-3, SCF, IL-2R $\alpha$, CTACK (CCL27), TRAIL (CD253), VCAM-1 (CD106), IL-12p40, MCP-3 (CCL7), M-CSF, RANTES (CCR5), IP-10 (CXCL10), ICAM-1 (CD54), HGF, SCGF- $\beta$, MIG (CXCR3), MIP-1 $\beta$ (CCL4), IL-18, G-CSF, LIF, SDF-1 $\alpha$ (CXCL12), and VEGF, were all significantly elevated in patients with $\mathrm{CHC}$ as compared to healthy individuals (Figure 4B). Other mediators including IL-17, MIF, GRO $\alpha$, and FGF were, however, down-regulated in patients with $\mathrm{CHC}$. To identify a possible link to the phenotype of $\mathrm{CD} 8^{+} \mathrm{T}$ cells, we then performed correlation analyses between the levels of plasma cytokines and chemokines and co-regulatory receptor expression
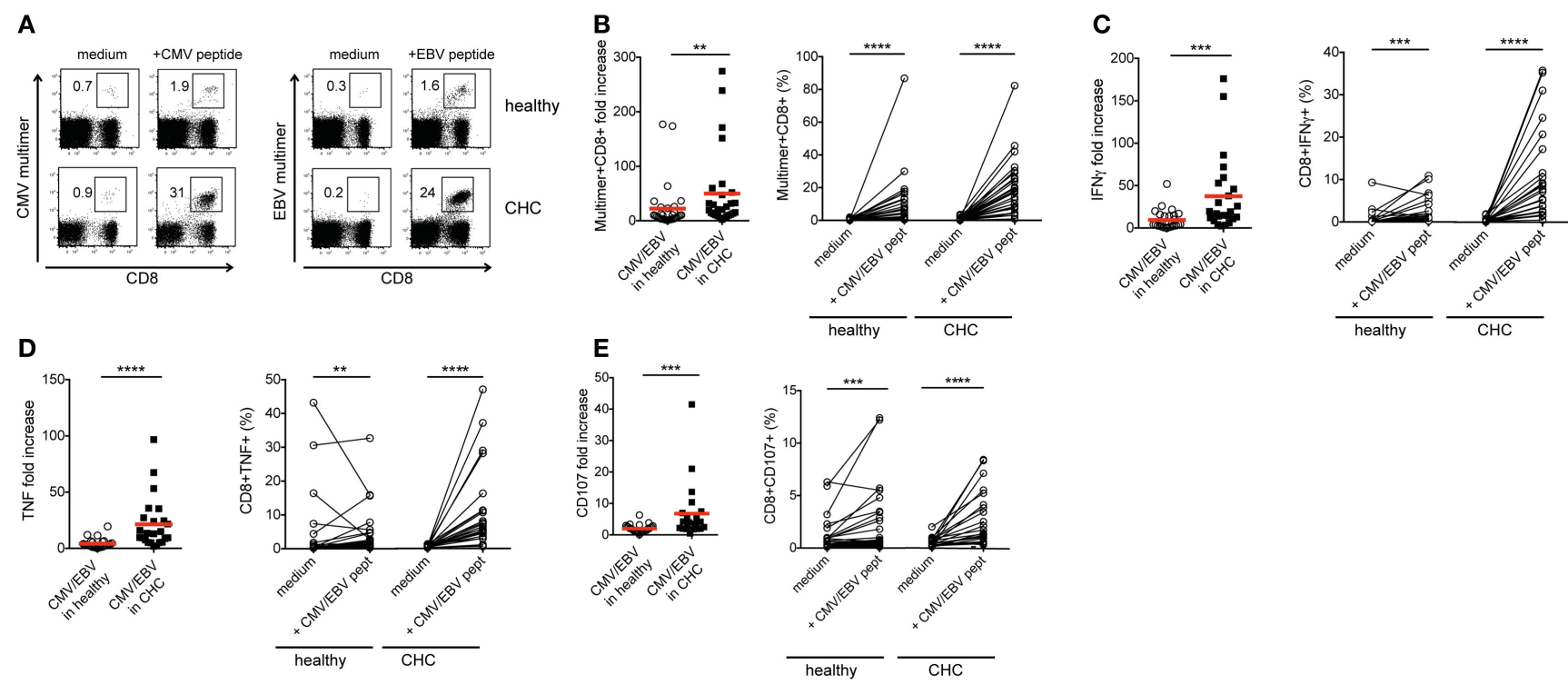

FIGURE 3 | Proliferation and cytokine production in vitro by CMV-/EBV-specific $\mathrm{CD}^{+}{ }^{+} \mathrm{T}$ cells from $\mathrm{CHC}$ patients and healthy individuals. PBMCs from patients with $\mathrm{CHC}(n=32)$ and healthy individuals $(n=28)$ were stimulated with CMV- or EBV-specific peptides in vitro for 10 days. (A) Representative FACS plots for staining of CMV- and EBV-specific $\mathrm{CD}^{+} \mathrm{T}$ cells and (B) pooled data show an increased fold expansion of CMV-(Healthy: CHC, $n=16: 13$ ) and EBV-(Healthy:CHC, $n=16: 15)$ specific CD8 ${ }^{+}$T cells in $\mathrm{CHC}$ patients compared to healthy individuals. (C) Fold increases of IFN $\gamma$ - and (D) TNF production as well as (E) CD107-expression on CMV-(Healthy: CHC,

$n=14: 11)$ and EBV-(Healthy:CHC, $n=13: 13)$ specific CD8 ${ }^{+}$T cells upon stimulation with CMV- or EBV-specific peptides in vitro were stronger in $\mathrm{CHC}$ patients as compared to healthy controls. Graphs on the left hand side show fold increases induced by peptide stimulation in comparison to unstimulated (medium only) controls. Right hand graphs show individual absolute frequencies for healthy individuals and $\mathrm{CHC}$ patients found for medium controls and peptide-stimulated cells. Red horizontal bars indicate mean values. Cells were gated on lymphocytes and total $\mathrm{CD}^{+}{ }^{+} \mathrm{T}$ cells after exclusion of dump channel. 

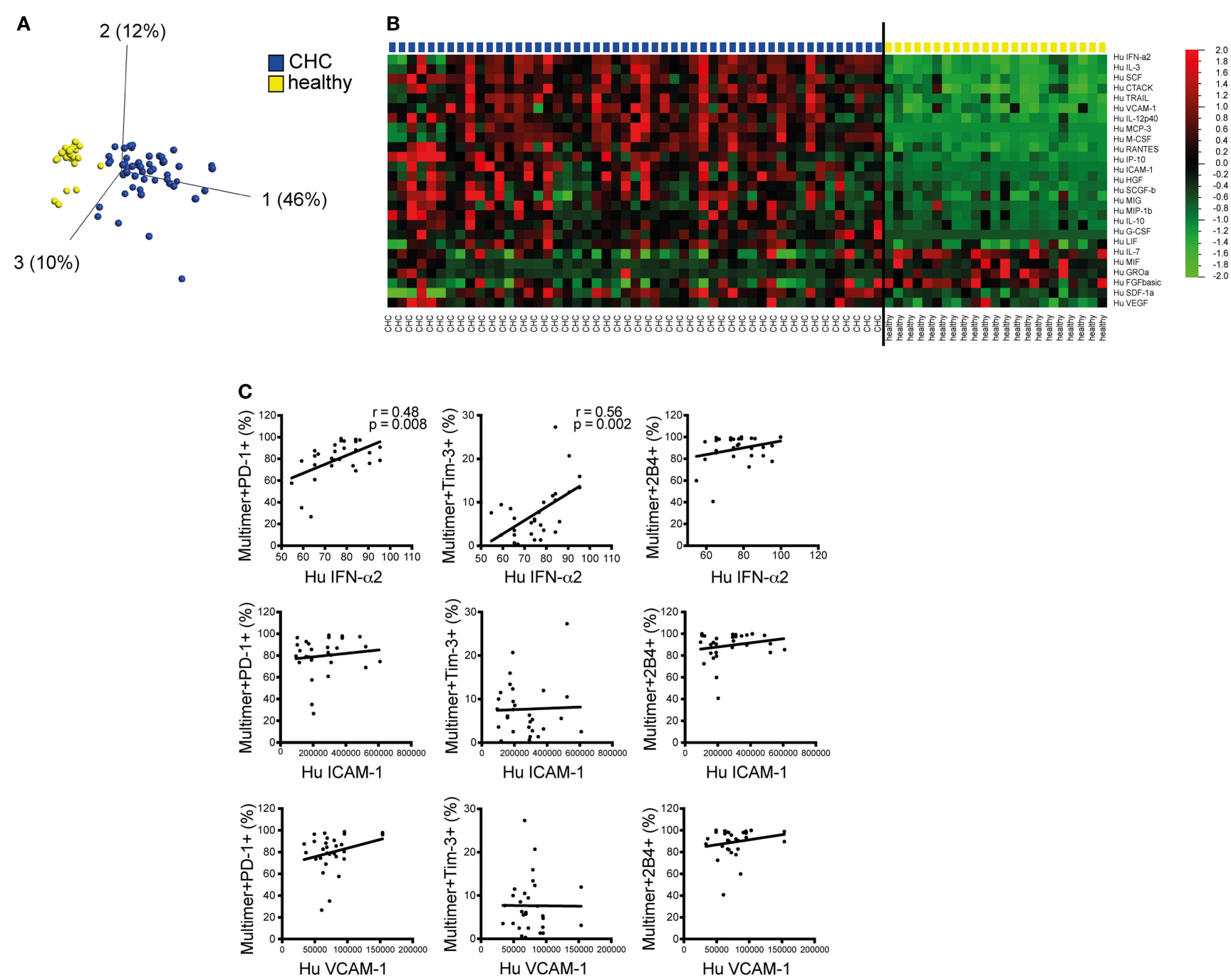

FIGURE 4 | Differences of and association of plasma cytokine/chemokine levels with ex vivo expression of distinct co-regulatory receptors on CMV/EBV-specific $\mathrm{CD}^{+}{ }^{+} \mathrm{T}$ cells in $\mathbf{C H C}$ patients. Fifty cytokines and chemokines were measured in the plasma of $\mathrm{CHC}$ patients without prior treatment and healthy controls by a multiplex assay. (A) Principal component analysis showed a distinct clusterization of $\mathrm{CHC}$ patients (blue) and healthy individuals (yellow) based on the differential concentrations of plasma cytokines and chemokines. (B) Heat map comparing

plasma cytokine/chemokine levels showed cytokines and chemokines with significantly differential concentrations between $\mathrm{CHC}$ patients and healthy individuals. (C) Correlation analysis of IFN- $\alpha 2$, VCAM-1 (CD106), and ICAM-1 (CD54) with co-regulatory receptor expression revealed a positive correlation of IFN- $\alpha 2$ plasma levels with PD-1 and Tim-3 expression ex vivo. Each patient's FACS data were correlated individually to the same patient's cytokine data obtained from the multiplex assay. $p$ - and $r^{2}$-values are indicated. Cells were gated on lymphocytes and total CD8 ${ }^{+} \mathrm{T}$ cells after exclusion of dump channel.

on CMV- and EBV-specific CD8 ${ }^{+}{ }^{-}$cells ex vivo on an individual basis comparing the respective patient's FACS data with the cytokine values obtained from the multiplex assay (Figure 4C). For representation purposes, we selected the three recombinant human proteins VCAM-1, ICAM-1, and IFN $\alpha$-2a that were further used for in vitro stimulation experiments. These proteins were selected based on their elevated plasma levels in CHC patients, literature-proven $\mathrm{T}$ cell co-stimulatory effects inducing cell signaling, presence of their respective receptors on $\mathrm{T}$ cells as well as their correlation with PD-1, Tim-3, or 2B4 ex vivo expression. Our results demonstrated a significant positive correlation of IFN $\alpha-2 \mathrm{a}$ plasma levels with PD-1 and Tim-3 expressions (Figure 4C). The seemingly positive correlation between IFN $\alpha-2 \mathrm{a}$ and $2 \mathrm{~B} 4$ expressions, however, did not reach statistical significance. Apart from IFN $\alpha-2 \mathrm{a}$ other components of the $\mathrm{HCV}$-induced inflammatory milieu such as IP-10, SDF, RANTES, SCF, and IL-18 positively correlated with at least one of PD-1, Tim-3, or 2B4 expression ex vivo (data not shown). By contrast, no correlation was observed between plasma concentrations of VCAM-1 and ICAM-1 (two adhesion molecules that were also up-regulated in $\mathrm{CHC}$ patients) with PD-1, Tim-3, or 2B4 expression (Figure 4C). These results hinted a role of IFN $\alpha-2 \mathrm{a}$ in influencing co-regulatory receptor upregulation on $\mathrm{CMV}$ - and $\mathrm{EBV}$-specific $\mathrm{CD} 8^{+} \mathrm{T}$ cells in patients with CHC. 


\section{In vitro IFN $\alpha$ Stimulation Converted the \\ Phenotype of CMV-/EBV-Specific CD8 ${ }^{+} \mathrm{T}$ Cells in Healthy Individuals to Those in Patients with CHC}

To further investigate whether the alterations of PD-1, Tim-3, and 2B4 expression patterns are indeed induced by cytokine/chemokine stimulations, we stimulated PBMC in vitro from healthy blood donors with different concentrations of selected recombinant human proteins for 10 days in the presence of CMV- or EBV-specific peptides. Our selected recombinant human proteins included VCAM-1, ICAM-1, and IFN $\alpha-2$ a.
Here, our aim was to assess the ability of the selected soluble mediators to convert the phenotype of CMV- and EBV-specific $\mathrm{CD}^{+} \mathrm{T}$ cells from healthy donors into those that were found in patients with CHC. In our analyses, no effect of VCAM-1 or ICAM-1 stimulation on the expression of PD-1, Tim-3, or 2B4 on CMV- and EBV-specific $\mathrm{CD}^{+}{ }^{+} \mathrm{T}$ cells was evident (Figure 5A). Interestingly, however, stimulation with IFN $\alpha-2 a$ in vitro resulted in a consistent dose-dependent upregulation of PD-1 and Tim-3 expressions. This was reflected not only in the frequencies of positive cells but also in the expression levels (MFI)

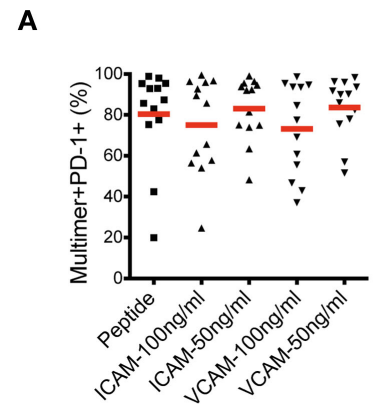

B
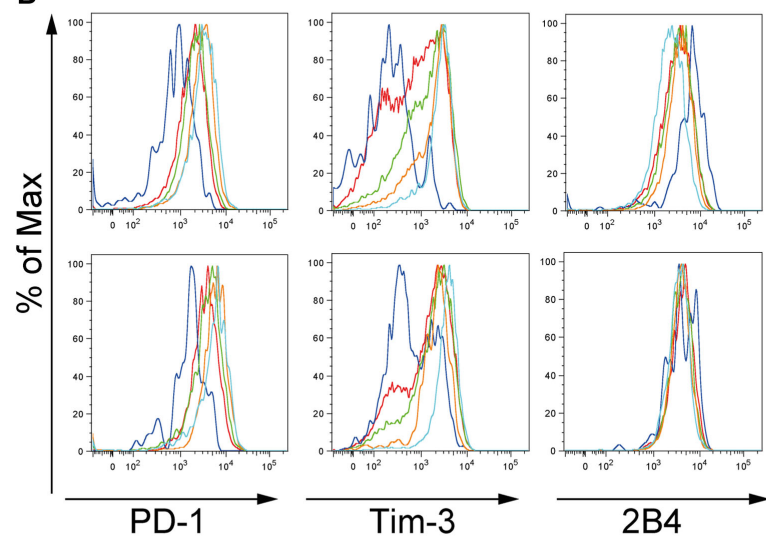

CMV

EBV

\section{Sample}

Peptide+IFNa - 1000ng/ml

Peptide+IFNa - 100ng/ml

Peptide+IFNa - 10ng/ml

Medium

Peptide only
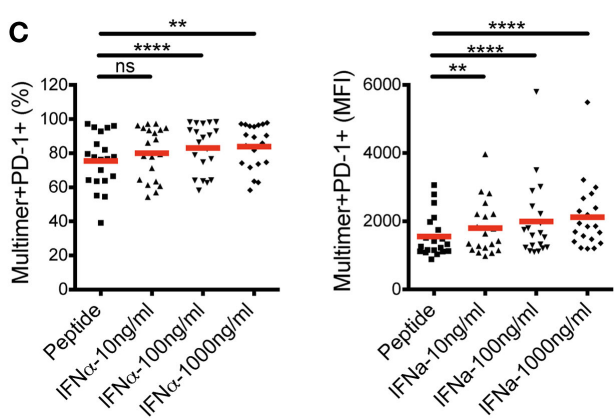

D
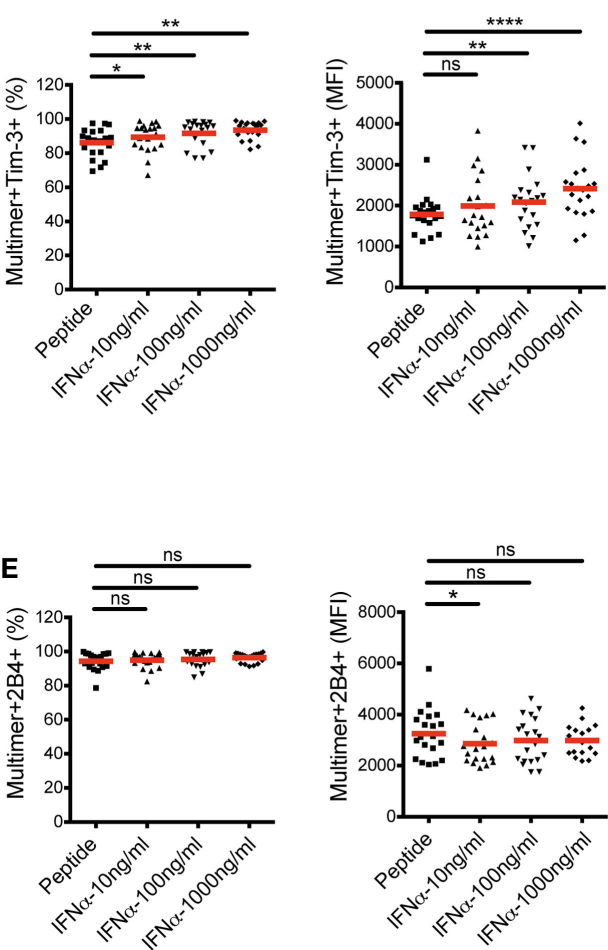

FIGURE 5 | Effect of in vitro cytokine/chemokine stimulation on the phenotype of CMV- and EBV-specific CD8 ${ }^{+} \mathbf{T}$ cells in healthy blood donors. Expression of PD-1, Tim-3, and 2B4 was analyzed on CMV- and EBV-specific CD8 ${ }^{+}$T cells in PBMC from healthy blood donors $(n=16)$ after stimulation with selected proteins together with virus-specific peptides. (A) Stimulation with different concentrations of VCAM-1 (CD106) or ICAM-1 (CD54) did not alter the expression of PD-1, Tim-3, or 2B4 on CMV-/EBV-specific CD8 ${ }^{+}$T cell responses $(n=13)$. (B) Representative FACS histogram overlays showing the frequencies and the expression intensities
(MFIs) of PD-1, Tim-3, and 2B4 upon stimulation with different concentrations of IFN- $\alpha 2$. One healthy individual is shown as representative. Stimulation with IFN $\alpha-2$ in vitro resulted in a consistent upregulation of both the frequency (left) and MFI (right) of (C) PD-1, and (D) Tim-3 expression or (E) down-regulation of 2B4 expression on CMV-/EBV-specific $\mathrm{CD}^{+}{ }^{+} \mathrm{T}$ cells in a dose-dependent manner. In vitro stimulation assay with VCAM-1 and ICAM-1 was performed in a separate experiment from that with IFN $\alpha-2$. Red horizontal bars indicate mean values. Cells were gated on lymphocytes and total $\mathrm{CD} 8^{+} \mathrm{T}$ cells after exclusion of dump channel. 
(Figures 5B-D). The expression of $2 \mathrm{~B} 4$ on IFN $\alpha$-stimulated $\mathrm{CMV}$ - and EBV-specific $\mathrm{CD}^{+}{ }^{+} \mathrm{T}$ cells in healthy individuals was reminiscent of the phenotype we observed earlier in $\mathrm{CHC}$ patients (Figure 5E). Although Tim-3 expression was marginally up-regulated, stimulation of PBMCs from healthy individuals with only IFN $\alpha$-2a without any virus-specific peptides, however, did not result in any considerable effect suggesting an antigendependent effect of IFN $\alpha$-2a stimulation on the modulation of $\mathrm{T}$ cell co-regulatory receptor expression (data not shown).

\section{Treatment-Induced HCV Clearance Resulted in a Partial Reversion of the Phenotype of CMV-/EBV-Specific CD8 ${ }^{+}$T Cells}

Our previous data demonstrated that the cytokine milieu can impact the phenotype of CMV-and EBV-specific $\mathrm{CD}^{+} \mathrm{T}$ cells leading to an enhanced expression of co-regulatory molecules. We next asked whether an antiviral therapy-induced clearance of HCV RNA would then lead to a reversion of the phenotype of $\mathrm{CMV}$ - and EBV-specific $\mathrm{CD}^{+}{ }^{+} \mathrm{T}$ cells to that found in healthy individuals by causing a decrease in $\mathrm{PD}-1$, Tim-3, and 2B4 expressions. To address this, we used PBMC from seven patients with $\mathrm{CHC}$ who had undergone successful antiviral treatment based on the novel IFN-free sofosbuvir administration. CMV- and EBVspecific $\mathrm{CD}^{+} \mathrm{T}$ cells from these samples were analyzed ex vivo at baseline (before treatment) and follow-up week 12 (FuW12). We did not observe any differences in the frequency of CMV-/EBVspecific $\mathrm{CD}^{+}{ }^{+} \mathrm{T}$ cells between baseline and FuW12 ex vivo and also not in the absolute cell count of these cells (Figure 6A). This observation was the same for both CMV-and EBV-specific $\mathrm{CD} 8^{+}$ $\mathrm{T}$ cells, demonstrating that the survival of these cells is not affected by the treatment. However, comparing the co-regulatory receptor expression between the two time points, we could observe a significant reduction in both the frequency (\%) and MFI of PD-1 expression at FuW12 (Figures 6B,C). The frequency of Tim3-expressing CMV-/EBV-specific $\mathrm{CD}^{+} \mathrm{T}$ cells also decreased significantly at FuW12, although this was not reflected in the MFI (Figure 6D). The expression of 2B4 remained almost unaltered between baseline and FuW12 except for a borderline significance, which was recorded for its MFI (Figure 6E). In accordance with this, the plasma levels of cytokines/chemokines measured by multiplex assay changed upon therapy-induced resolution of infection (data not shown). Importantly, IFN $\alpha$ levels decreased significantly until FuW12 (Figure 6F), which is in correlation to the observed change of the phenotype of CMV- and EBV-specific $\mathrm{CD}^{+} \mathrm{T}$ cells. Overall, this data further strengthen the hypothesis that the phenotype of CMV- and EBV-specific CD8 $\mathrm{T}^{+}$cells is affected by the inflammatory cytokine milieu present during persistent $\mathrm{HCV}$ infection.

\section{Discussion}

Overexpression of distinct co-regulatory receptors such as PD-1, CTLA-4, Tim-3, Lag-3, and 2B4 has been previously described and strongly considered as a fingerprint for exhausted $\mathrm{T}$ cells. Particularly, in many persistent virus infections where $\mathrm{T}$ cells have been shown to have an impaired proliferative capacity

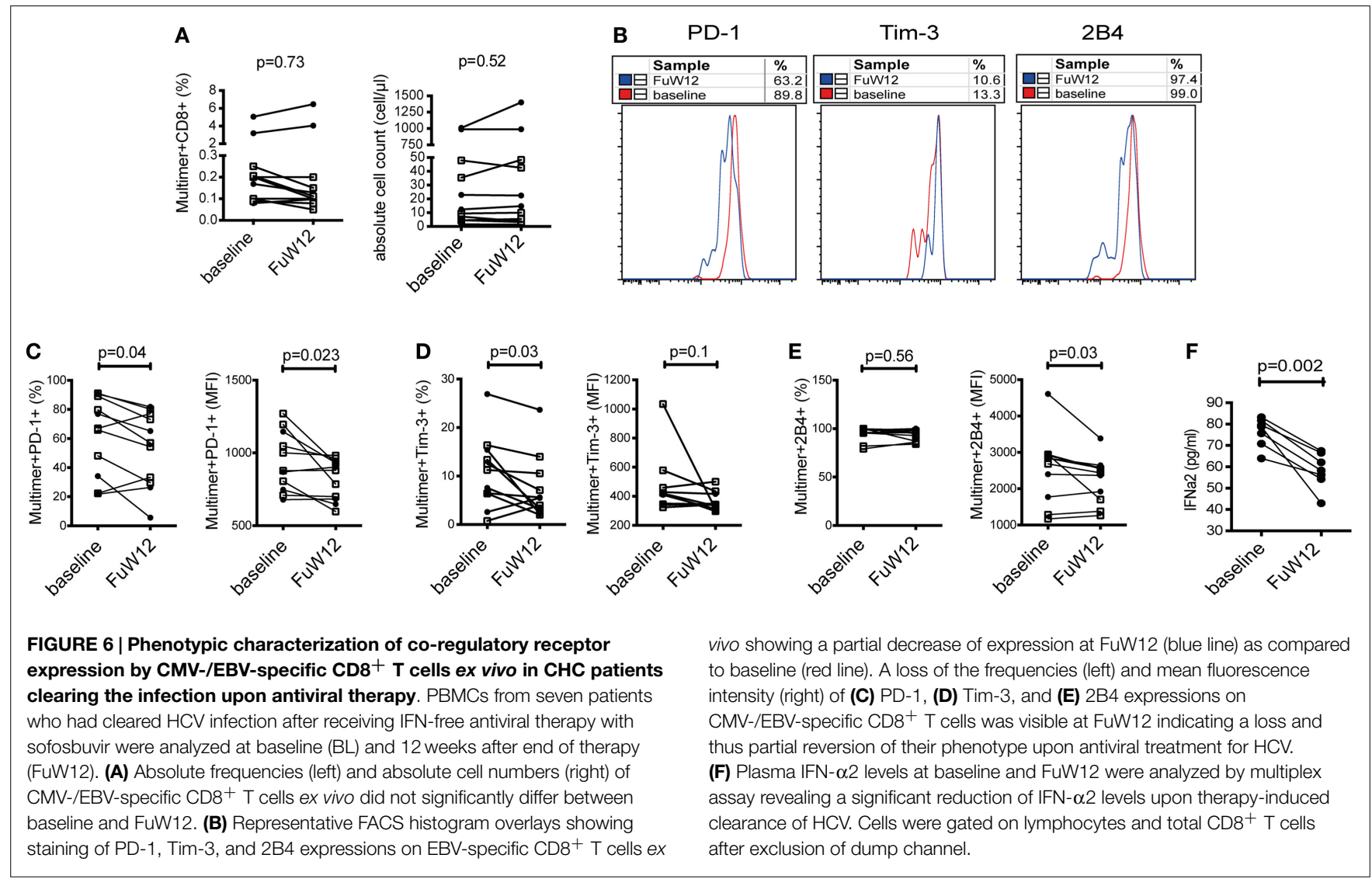


and functionality, upregulation of various co-regulatory receptors have been observed. In this context, it has been suggested that co-regulatory receptor overexpression is a way the immune system prevents uncontrolled inflammation and pathology due to the constant antigen stimulation. However, antigen stimulation alone does not seem to be the only driving force behind coregulatory receptor upregulation. Indeed, several studies have demonstrated both antigen-dependent and -independent mechanisms that are capable of increasing co-regulatory receptor expression. For example, antigen specificity, cell differentiation, and the microenvironment were found to strongly influence the expression of co-regulatory receptors on $\mathrm{CD}^{+} \mathrm{T}$ cells (21-23). Using $\mathrm{HCV}$ as a model of persistent virus infection in humans, we comprehensively investigated the influence inflammatory mediators induced during persistent infections have on co-regulatory receptor expression by $\mathrm{CD} 8^{+} \mathrm{T}$ cells specific for the common pathogens CMV and EBV. Both CMV and EBV are particularly ubiquitous in the human population where they usually have a lifelong persistence in the infected host. Virus-specific $\mathrm{CD} 8^{+} \mathrm{T}$ cell populations targeting the two viruses are often larger and ex vivo detectability is high. These attributes informed our choice of studying the two viruses and afforded us the opportunity to examine the effects of HCV's persistence on an unrelated antigenspecific $\mathrm{T}$ cell population in clear, unambiguous terms using the MHC-I multimer technology.

Evaluating co-regulatory receptor expression by antigenspecific $\mathrm{CD}^{+} \mathrm{T}$ cells, we observed that PD-1-, Tim-3-, and 2B4expressing $\mathrm{CMV}$ - and $\mathrm{EBV}$-specific $\mathrm{CD} 8^{+} \mathrm{T}$ cells were enriched in patients with $\mathrm{CHC}$ compared to their counterparts in uninfected controls. The increased frequencies of CMV-specific CD8 ${ }^{+} \mathrm{T}$ cells expressing Tim-3 in patients with $\mathrm{CHC}$ compared to uninfected controls was previously shown (24). Our findings here, derived from a larger group of patients, thus confirm and significantly extend the previous report even further with two additional coregulatory molecules (PD-1 and 2B4) prominent in persistent infections. We further observed that persistent $\mathrm{HCV}$ infection not only influenced co-regulatory receptor expression by antigenspecific $\mathrm{CD}^{+} \mathrm{T}$ cells of viruses unrelated to $\mathrm{HCV}$ but also impacted the phenotype of total $\mathrm{CD}^{+} \mathrm{T}$ cells. The strikingly high expression of PD-1, Tim-3, and $2 \mathrm{~B} 4$ by the total $\mathrm{CD} 8^{+} \mathrm{T}$ cell population in persistent $\mathrm{HCV}$ infection is indicative of the pervasive global influence persistent $\mathrm{HCV}$ has on the phenotype of T cells, beyond those that are HCV-specific. We further have data published recently showing that the enhanced functionality of immune cells during $\mathrm{CHC}$ is not restricted to $\mathrm{CD}^{+} \mathrm{T}$ cells, but that a similar elevated functionality can be observed for NK cells as well (25). Certainly, these observations called into question the actual role of co-regulatory receptor expression on antiviral $\mathrm{T}$ cell immunity in disease. Indeed, the association of functional exhaustion to the elevated expression of co-regulatory receptors in patients with $\mathrm{CHC}$ has been well established $(3,26)$. However, apart from this report, high PD-1 and 2B4 expressions on functionally competent CMV- and/or EBV-specific CD8 ${ }^{+} \mathrm{T}$ cells in patients with $\mathrm{CHC}$ have also been demonstrated before $(16,20,27)$. Moreover, we demonstrated in a recent report that PD-1 and 2B4 expressions by CMV- and EBV-specific CD8 ${ }^{+} \mathrm{T}$ cells in patients with $\mathrm{CHC}$ were significantly higher compared to exhausted HCV-specific CD8 ${ }^{+}{ }^{-}$cells in the same patients (28). Again, Kroy et al. who extensively characterized co-regulatory receptor expression on $\mathrm{CD}^{+} \mathrm{T}$ cells on IHLs also revealed that IHLs from liver tissue without infection, inflammation, or malignancy displayed the same patterns of PD-1 and 2B4 expressions as those with HCV infection (22). Strengthened by previous observations, our findings here therefore water down the heightened assumption and reference of co-regulatory receptor molecules as "classical markers of exhaustion." Further, it strongly supports the notion that enrichment of co-regulatory receptor expression (especially PD-1 and 2B4) may be a mere physiological response to the microenvironment and not necessarily a reflection of a failing immune response in disease.

In many persistent virus infections, the expression of multiple co-regulatory receptors has been tightly linked to a reduced proliferation and cytokine production $(29,30)$. In recent years, however, it is becoming increasingly evident that co-regulatory receptor expression may not solely drive the functional impairment of effector $\mathrm{CD}^{+}{ }^{+} \mathrm{T}$ cells. Many independent investigations have otherwise shown that co-regulatory receptor-positive $\mathrm{CD} 8^{+} \mathrm{T}$ cells in peripheral blood of healthy donors are not necessarily functionally impaired $(23,31,32)$. Instead, PD-1 expression correlated with positive $T$ cell function and with activation markers such as CD38 in HIV infection as reviewed in Ref. (33) or CD137 in breast cancer studies (34). Guided by these observations, we sought to ascertain the functional consequence of the $\mathrm{HCV}$-induced upregulation of PD-1, Tim-3, and 2B4 on the CMV- and EBV-specific CD8 ${ }^{+} \mathrm{T}$ cells in $\mathrm{CHC}$ patients compared to healthy donors. We observed significantly enhanced functional responses upon peptide stimulation, which was distinctive to CMV- and EBV-specific $\mathrm{CD} 8^{+} \mathrm{T}$ cells exposed to the inflammatory milieu in persistent $\mathrm{HCV}$ infection. Ostensibly, this observation was made concomitant to a relative upregulation of co-regulatory receptor expression through TCR stimulation with cognate peptides in vitro. This observation was exceptionally interesting as it particularly linked immune activation with co-regulatory receptor upregulation and improved functional responses (at least for CMV- and EBV-specific CD8 ${ }^{+}$ $\mathrm{T}$ cells) as has been suggested before (23). Further, stratifying our samples by the ex vivo expression levels of co-regulatory receptors revealed that there is no difference in the in vitro proliferative responses between ex vivo low and high expressing samples and this held true for both healthy individuals and $\mathrm{CHC}$ patients. Overall, these observations suggest that PD- 1 or Tim-3 expression per se do not necessarily make T cells exhausted and dysfunctional, but that additional and so far unknown events appear to be crucial to convert these molecules into actual inhibitors. Further, these data point to a much profound conditioning of CMV- and EBVspecific $\mathrm{CD}^{+} \mathrm{T}$ cells by the inflammatory milieu in patients with $\mathrm{CHC}$, which alters co-regulatory receptor expression, and the cells benefiting thereof with an improved functional responses.

The changes in phenotype and function during $\mathrm{CHC}$ were visible and common for both CMV- and EBV-specific $\mathrm{CD} 8^{+} \mathrm{T}$ cells with no major differences apparent. This suggests that broad and general factors seem to drive these changes and not virusspecific ones. This becomes especially important in the light of a recent publication showing that CMV infection is one of the major non-heritable factors impacting the immune phenotype 
and response in humans (35). Despite that we can observe a slight correlation of the frequencies of $\mathrm{CMV}$-specific $\mathrm{CD} 8^{+} \mathrm{T}$ cells with age in our cohort of CHC patients, which is absent for EBVspecific $\mathrm{CD}^{+} \mathrm{T}$ cells, again in both cases the change of frequency, phenotype, and function can be seen for both virus specificities. Further, also among our healthy cohort individuals are included that are infected with CMV as well, thus a CMV-specific impact as described by Brodin et al. (35) does not seem to be the major force driving our observations. However, our findings are nevertheless in line with the publication by Brodin et al., as we also show that environment influences and other infections (in our case HCV) seem to alter and shape the immune system.

The presence of assortments of cytokine receptors on effector and memory antiviral $\mathrm{CD} 8^{+} \mathrm{T}$ cells enable them to respond to shifts in the cytokine milieu and may even allow them to circumvent their requirements for antigen-dependent activation (36). Recently, effector and memory $\mathrm{CD}^{+} \mathrm{T}$ cells' sensitivity to an expansive range of cytokines has been profiled (37). The effects of inflammatory mediators on the phenotypic changes of $\mathrm{CMV}$ - and EBV-specific CD8 ${ }^{+} \mathrm{T}$ cells observed in this study was therefore not so surprising following these previous reports. Interestingly, several of the inflammatory cytokines and plasma proteins from our study here, such as ICAM-1, VCAM-1, IFN$\alpha 2$, SDF- $1 \alpha$, and IL-18, that showed elevated concentrations in patients with $\mathrm{CHC}$ compared to healthy individuals have been associated with $\mathrm{T}$ cell activation (38-40). In fact, we show in this study for the first time that IFN- $\alpha 2$ was not only the differentially dominant component of the $\mathrm{HCV}$-induced inflammatory mediators but also positively correlated with co-regulatory receptor expression ex vivo. Interestingly, IFN- $\alpha 2$ further caused an expected upregulation of PD-1 and Tim-3 expression on CMVand $\mathrm{EBV}$-specific $\mathrm{CD}^{+}{ }^{+} \mathrm{T}$ cells in healthy individuals in vitro. However, other mediators such as the adhesion molecules ICAM1 and VCAM-1 failed to replicate any of these IFN- $\alpha 2$ 's ex vivo behavior or in vitro effects. Nevertheless, these findings further confirm the profound effect some inflammatory mediators such as type I interferon may have on the phenotype of antiviral $\mathrm{CD}^{+} \mathrm{T}$ cells. It further suggests a specific importance of IFN-I in regulating antiviral $\mathrm{T}$ cell immunity through coregulatory receptor expression in order to protect them against killing by $\mathrm{NK}$ cells as a regulatory immune function as suggested previously (41).

The expression of 2B4 instead showed a decline of expression after INF- $\alpha 2$ stimulation in vitro, while the frequency of expression of PD-1 and Tim-3 was consistently increased. This different behavior of $2 \mathrm{~B} 4$ upon stimulation might be based on the fact that 2B4 is not a classical inhibitory receptor, but it rather has a dual function able to induce at least two different downstream signaling pathways, which subsequently elicit different cellular responses (i.e., either activation or inhibition) (42).

Previous studies by Wang et al. in patients with chronic hepatitis $B$ showed a reduction of PD- 1 and Tim- 3 expressions on $\mathrm{CD} 8^{+} \mathrm{T}$ cells following antiviral treatment against HBV (43). However, to our knowledge, no study has so far dissected whether the cessation of inflammation in patients with $\mathrm{CHC}$ revert the phenotype of CMV- and EBV-specific $\mathrm{CD}^{+}{ }^{+} \mathrm{T}$ cells hitherto induced by the inflammatory environment. The introduction of the novel
IFN-free therapy to cure HCV infection allowed us the unique opportunity to investigate the effects therapy-induced HCV clearance has on co-regulatory receptor expression on CMV- and EBVspecific $\mathrm{CD}^{+}{ }^{+} \mathrm{T}$ cells. Of note, HCV RNA shows a very rapid decline early after start of IFN-free therapy and the inflammatory activity of liver disease already dramatically reduces 7-14 days after therapy start (44) suggesting that cytokine patterns normalize rather soon during therapy. Comparing co-regulatory receptor expression between baseline and 12 weeks after the end of antiviral therapy, we observed that both the frequency and MFI of PD1 expression by CMV- and EBV-specific $\mathrm{CD}^{+}{ }^{+} \mathrm{T}$ cells reduced significantly after viral clearance. While only the frequency of Tim-3-expressing CMV- and EBV-specific CD8 ${ }^{+}$T cells experienced a significant decline, that of $2 \mathrm{~B} 4$ was reflected only in its MFI. These differential dynamics of PD-1, Tim-3, and 2B4 with an apparently earlier and faster decline of PD-1 expression is noteworthy and it would be interesting to see the long-term effects of successful HCV clearance. Further, this partial normalization of co-regulatory receptor expression by pathogens unrelated to $\mathrm{HCV}$ following a treatment that directly targets HCV reflects the development of antigen-independent immune homeostasis upon antiviral therapy in patients with $\mathrm{CHC}$.

The change of the phenotype of CMV- and EBV-specific $\mathrm{CD}^{+} \mathrm{T}$ cells in $\mathrm{CHC}$ patients is accompanied by an elevated frequency of cells and an enhanced functionality in vitro. While the change of phenotype might at least partially be explained by the influence of IFN $\alpha$, which is drastically elevated during $\mathrm{CHC}$, the means behind the increased functionality remains unclear. One possible explanation might be a shift in the expression of STAT transcription factors and subsequently induced ISGs, as we and others could previously show to be the case for the enhanced functionality of NK cells in CHC patients $(25,45)$. It might well be that similar mechanisms also apply for $\mathrm{CD}^{+} \mathrm{T}$ cells as demonstrated recently in mice (46). However, preliminary data suggest that mechanism(s) other than IFN $\alpha$ stimulation seems to drive these changes. Despite a clear decline of plasma IFN $\alpha$ levels associated with a reversion of the phenotype of CMVand EBV-specific CD8 ${ }^{+} \mathrm{T}$ cells in $\mathrm{CHC}$ patients successfully treated with the direct-acting antivirals sofosbuvir as shown here, the frequency and functionality of these cells did not change at FuW12 (data not shown).

The data presented here show the broad and pervasive influence HCV has on the immune system and other immune cells, besides the HCV-specific ones. Here, this manifests itself by the alteration of the properties of CMV- and EBV-specific CD8 ${ }^{+} \mathrm{T}$ cells and by the change of plasma cytokines in patients with $\mathrm{CHC}$. It is justified to assume that these effects also extend to other cells of the adaptive (i.e., besides CMV- and EBV-specific $\mathrm{CD}^{+}{ }^{+} \mathrm{T}$ cells) and innate immune system (e.g., NK cells, dendritic cells, monocytes). Apart from the hitherto described impact of IFN $\alpha$, several other reasons and mechanisms might contribute as well. For instance, other cytokines and inflammatory mediators elevated or decreased during persistent infection might contribute to the conditioning of immune cells. In this regard, also the homeostatic proliferation of immune cells regulated by several cytokines might be affected leading to the here described alterations. Further, direct antigen-specific effects generated, e.g., by $\mathrm{T}$ cell 
cross-reactivity might apply as described for other scenarios (47, 48). Importantly, our data presented here are in line and extend the influence that viral infections might have on immune cell populations, phenotype, and function as recently described for CMV in studies of twin pairs (35) and enlarge the portfolio of influencing factors to include HCV as well.

In summary, this study presents a two-fold level of relevance. First, they indicate that a persistent infection with $\mathrm{HCV}$ cannot be considered in isolation as it may have far-ranging effects on the global $\mathrm{CD}^{+} \mathrm{T}$ cell population as well as on antigenspecific $\mathrm{CD}^{+}{ }^{+} \mathrm{T}$ cell immunity against unrelated pathogens such as CMV and EBV. Here, persistent $\mathrm{HCV}$-induced up-regulated expression of co-regulatory receptors PD-1, Tim-3, and 2B4 on in vitro-verified, functionally competent CMV- and EBVspecific $\mathrm{CD}^{+}{ }^{+} \mathrm{T}$ cells. This mechanism suggests that distinct coregulatory receptors are expressed concomitantly with various inflammatory factors, which boosts functionality but negatively regulate the immune response upon reaching a threshold. Second, they provide a handle to investigate the mechanisms regulating epitope-specific $\mathrm{CD}^{+} \mathrm{T}$ cell function in general, which might be of clinical relevance considering the rather high incidence of a broad array of co-morbidities observed in patients with $\mathrm{CHC}$. These data further give insight into the regulation of antiviral pathogen-specific $\mathrm{CD}^{+} \mathrm{T}$ cell responses, especially during clinically relevant virus co-infections in humans such as $\mathrm{HCV} / \mathrm{HBV}$,

\section{References}

1. Gower E, Estes C, Blach S, Razavi-Shearer K, Razavi H. Global epidemiology and genotype distribution of the hepatitis C virus infection. J Hepatol (2014) 61(1 Suppl):S45-57. doi:10.1016/j.jhep.2014.07.027

2. Park SH, Rehermann B. Immune responses to HCV and other hepatitis viruses. Immunity (2014) 40(1):13-24. doi:10.1016/j.immuni.2013.12.010

3. Klenerman P, Thimme R. T cell responses in hepatitis C: the good, the bad and the unconventional. Gut (2012) 61(8):1226-34. doi:10.1136/ gutjnl-2011-300620

4. Bowen DG, Walker CM. Adaptive immune responses in acute and chronic hepatitis C virus infection. Nature (2005) 436(7053):946-52. doi:10.1038/ nature 04079

5. Fallahi P, Ferri C, Ferrari SM, Corrado A, Sansonno D, Antonelli A. Cytokines and HCV-related disorders. Clin Dev Immunol (2012) 2012:468107. doi:10. $1155 / 2012 / 468107$

6. Fahey S, Dempsey E, Long A. The role of chemokines in acute and chronic hepatitis C infection. Cell Mol Immunol (2014) 11(1):25-40. doi:10.1038/cmi. 2013.37

7. Cacoub P, Gragnani L, Comarmond C, Zignego AL. Extrahepatic manifestations of chronic hepatitis C virus infection. Dig Liver Dis (2014) 46(Suppl 5):S165-73. doi:10.1016/j.dld.2014.10.005

8. Keeffe EB, Iwarson S, McMahon BJ, Lindsay KL, Koff RS, Manns M, et al. Safety and immunogenicity of hepatitis A vaccine in patients with chronic liver disease. Hepatology (1998) 27(3):881-6. doi:10.1002/hep.510270336

9. Majda-Stanislawska E, Bednarek M, Kuydowicz J. Immunogenicity of inactivated hepatitis A vaccine in children with chronic liver disease. Pediatr Infect Dis J (2004) 23(6):571-4. doi:10.1097/01.inf.0000130076.33497.6c

10. Wiedmann M, Liebert UG, Oesen U, Porst H, Wiese M, Schroeder S, et al. Decreased immunogenicity of recombinant hepatitis B vaccine in chronic hepatitis C. Hepatology (2000) 31(1):230-4. doi:10.1002/hep.510310134

11. Moorman JP, Zhang CL, Ni L, Ma CJ, Zhang Y, Wu XY, et al. Impaired hepatitis $\mathrm{B}$ vaccine responses during chronic hepatitis $\mathrm{C}$ infection: involvement of the PD-1 pathway in regulating CD4(+) T cell responses. Vaccine (2011) 29(17):3169-76. doi:10.1016/j.vaccine.2011.02.052

12. Gaeta GB, Stornaiuolo G, Precone DF, Amendola A, Zanetti AR. Immunogenicity and safety of an adjuvanted influenza vaccine in patients with
$\mathrm{HCV} / \mathrm{HIV}$, and HBV/HDV. Given the severity of disease associated with co-infections and the difficulty in treating same, such knowledge would particularly be relevant for the development of better therapeutic options.

\section{Acknowledgments}

We would like to thank all medical doctors and study nurses at the liver Outpatient clinic of MHH. Also, we are grateful to all patients and healthy volunteers who donated blood to this study. We would like to further thank Kerstin Daemen for performing the Luminex assays. This work was supported by the Collaborative Research Centre SFB900 'Chronic Infections: Microbial Persistence and its Control' (Project A5), by the Collaborative Research Centre SFB738 'Optimization of conventional and innovative transplants' (Projects B2, B8) and by the Center of Infection Biology of the Hannover Biomedical Research School funded by the Ministry of Science and Culture of Lower Saxony.

\section{Supplementary Material}

The Supplementary Material for this article can be found online at http://journal.frontiersin.org/article/10.3389/fimmu.2015.00270/ abstract

decompensated cirrhosis. Vaccine (2002) 20(Suppl 5):B33-5. doi:10.1016/ S0264-410X(02)00510-8

13. Monaco S, Ferrari S, Gajofatto A, Zanusso G, Mariotto S. HCV-related nervous system disorders. Clin Dev Immunol (2012) 2012:236148. doi:10.1155/2012/ 236148

14. van Riet E, Adegnika AA, Retra K, Vieira R, Tielens AG, Lell B, et al. Cellular and humoral responses to influenza in gabonese children living in rural and semi-urban areas. J Infect Dis (2007) 196(11):1671-8. doi:10.1086/522010

15. Harcourt GC, Donfield S, Gomperts E, Daar ES, Goulder P Jr, Phillips RE, et al. Longitudinal analysis of CD8 T-cell responses to HIV and hepatitis C virus in a cohort of co-infected haemophiliacs. AIDS (2005) 19(11):1135-43. doi:10.1097/01.aids.0000176213.10367.05

16. Lucas M, Vargas-Cuero AL, Lauer GM, Barnes E, Willberg CB, Semmo N, et al. Pervasive influence of hepatitis $\mathrm{C}$ virus on the phenotype of antiviral CD8+ T cells. J Immunol (2004) 172(3):1744-53. doi:10.4049/jimmunol.172.3.1744

17. Stelekati E, Shin H, Doering TA, Dolfi DV, Ziegler CG, Beiting DP, et al. Bystander chronic infection negatively impacts development of CD8(+) T cell memory. Immunity (2014) 40(5):801-13. doi:10.1016/j.immuni.2014.04.010

18. Penna A, Pilli M, Zerbini A, Orlandini A, Mezzadri S, Sacchelli L, et al. Dysfunction and functional restoration of $\mathrm{HCV}$-specific $\mathrm{CD} 8$ responses in chronic hepatitis C virus infection. Hepatology (2007) 45(3):588-601. doi:10.1002/hep. 21541

19. Suneetha PV, Schlaphoff V, Wang C, Stegmann KA, Fytili P, Sarin SK, et al Effect of peptide pools on effector functions of antigen-specific CD8+ T cells. J Immunol Methods (2009) 342(1-2):33-48. doi:10.1016/j.jim.2008.11.020

20. Schlaphoff V, Lunemann S, Suneetha PV, Jaroszewicz J, Grabowski J, Dietz J, et al. Dual function of the NK cell receptor 2B4 (CD244) in the regulation of HCV-specific CD8+ T cells. PLoS Pathog (2011) 7(5):e1002045. doi:10.1371/ journal.ppat.1002045

21. Baitsch L, Legat A, Barba L, Fuertes Marraco SA, Rivals JP, Baumgaertner P, et al. Extended co-expression of inhibitory receptors by human CD8 T-cells depending on differentiation, antigen-specificity and anatomical localization. PLoS One (2012) 7(2):e30852. doi:10.1371/journal.pone.0030852

22. Kroy DC, Ciuffreda D, Cooperrider JH, Tomlinson M, Hauck GD, Aneja J, et al. Liver environment and HCV replication affect human T-cell phenotype and expression of inhibitory receptors. Gastroenterology (2014) 146(2):550-61. doi:10.1053/j.gastro.2013.10.022 
23. Legat A, Speiser DE, Pircher H, Zehn D, Fuertes Marraco SA. Inhibitory receptor expression depends more dominantly on differentiation and activation than "exhaustion" of human CD8 T cells. Front Immunol (2013) 4:455. doi:10. 3389/fimmu.2013.00455

24. Golden-Mason L, Palmer BE, Kassam N, Townshend-Bulson L, Livingston S, McMahon BJ, et al. Negative immune regulator Tim-3 is overexpressed on $\mathrm{T}$ cells in hepatitis $\mathrm{C}$ virus infection and its blockade rescues dysfunctional CD4+ and CD8+ T cells. J Virol (2009) 83(18):9122-30. doi:10.1128/JVI.00639-09

25. Rogalska-Taranta M, Markova A, Taranta A, Lunemann S, Schlaphoff V, Flisiak $\mathrm{R}$, et al. Altered effector functions of NK cells in chronic hepatitis $\mathrm{C}$ are associated with IFNL3 polymorphism. J Leukocyte Bio (in press).

26. Wherry EJ. T cell exhaustion. Nat Immunol (2011) 12(6):492-9. doi:10.1038/ni. 2035

27. Golden-Mason L, Palmer B, Klarquist J, Mengshol JA, Castelblanco N, Rosen HR. Upregulation of PD-1 expression on circulating and intrahepatic hepatitis $\mathrm{C}$ virus-specific CD8+ T cells associated with reversible immune dysfunction. J Virol (2007) 81(17):9249-58. doi:10.1128/JVI.00409-07

28. Owusu Sekyere S, Suneetha PV, Kraft AR, Zhang S, Dietz J, Sarrazin C, et al. A heterogeneous hierarchy of co-regulatory receptors regulates exhaustion of HCV-specific CD8 T cells in patients with chronic hepatitis C. J Hepatol (2015) 62(1):31-40. doi:10.1016/j.jhep.2014.08.008

29. Bengsch B, Seigel B, Ruhl M, Timm J, Kuntz M, Blum HE, et al. Coexpression of PD-1, 2B4, CD160 and KLRG1 on exhausted HCV-specific CD8+ T cells is linked to antigen recognition and T cell differentiation. PLoS Pathog (2010) 6(6):e1000947. doi:10.1371/journal.ppat.1000947

30. Blackburn SD, Shin H, Haining WN, Zou T, Workman CJ, Polley A, et al. Coregulation of $\mathrm{CD} 8+\mathrm{T}$ cell exhaustion by multiple inhibitory receptors during chronic viral infection. Nat Immunol (2009) 10(1):29-37. doi:10.1038/ni.1679

31. Utzschneider DT, Legat A, Fuertes Marraco SA, Carrie L, Luescher I, Speiser $\mathrm{DE}$, et al. T cells maintain an exhausted phenotype after antigen withdrawal and population reexpansion. Nat Immunol (2013) 14(6):603-10. doi:10.1038/ ni. 2606

32. Duraiswamy J, Ibegbu CC, Masopust D, Miller JD, Araki K, Doho GH, et al. Phenotype, function, and gene expression profiles of programmed death-1(hi) CD8 T cells in healthy human adults. J Immunol (2011) 186(7):4200-12. doi:10. 4049/jimmunol.1001783

33. Khaitan A, Unutmaz D. Revisiting immune exhaustion during HIV infection. Curr HIV/AIDS Rep (2011) 8(1):4-11. doi:10.1007/s11904-010-0066-0

34. Verbrugge I, Hagekyriakou J, Sharp LL, Galli M, West A, McLaughlin NM, et al. Radiotherapy increases the permissiveness of established mammary tumors to rejection by immunomodulatory antibodies. Cancer Res (2012) 72(13):3163-74. doi:10.1158/0008-5472.CAN-12-0210

35. Brodin P, Jojic V, Gao T, Bhattacharya S, Angel CJ, Furman D, et al. Variation in the human immune system is largely driven by non-heritable influences. Cell (2015) 160(1-2):37-47. doi:10.1016/j.cell.2014.12.020

36. Berg RE, Forman J. The role of CD8 T cells in innate immunity and in antigen non-specific protection. Curr Opin Immunol (2006) 18(3):338-43. doi:10.1016/ j.coi.2006.03.010

37. Freeman BE, Hammarlund E, Raue HP, Slifka MK. Regulation of innate CD8+ T-cell activation mediated by cytokines. Proc Natl Acad Sci U S A (2012) 109(25):9971-6. doi:10.1073/pnas.1203543109
38. Cox MA, Kahan SM, Zajac AJ. Anti-viral CD8 T cells and the cytokines that they love. Virology (2013) 435(1):157-69. doi:10.1016/j.virol.2012.09.012

39. Kim JJ, Nottingham LK, Sin JI, Tsai A, Morrison L, Oh J, et al. CD8 positive $\mathrm{T}$ cells influence antigen-specific immune responses through the expression of chemokines. J Clin Invest (1998) 102(6):1112-24. doi:10.1172/ JCI3986

40. Bachmann MF, McKall-Faienza K, Schmits R, Bouchard D, Beach J, Speiser DE, et al. Distinct roles for LFA-1 and CD28 during activation of naive $\mathrm{T}$ cells: adhesion versus costimulation. Immunity (1997) 7(4):549-57. doi:10. 1016/S1074-7613(00)80376-3

41. Xu HC, Grusdat M, Pandyra AA, Polz R, Huang J, Sharma P, et al. Type I interferon protects antiviral CD8+ T cells from NK cell cytotoxicity. Immunity (2014) 40(6):949-60. doi:10.1016/j.immuni.2014.05.004

42. Chlewicki LK, Velikovsky CA, Balakrishnan V, Mariuzza RA, Kumar V. Molecular basis of the dual functions of 2B4 (CD244). J Immunol (2008) 180(12):8159-67. doi:10.4049/jimmunol.180.12.8159

43. Wang L, Zhao C, Peng Q, Shi J, Gu G. Expression levels of CD28, CTLA-4, PD-1 and Tim-3 as novel indicators of T-cell immune function in patients with chronic hepatitis B virus infection. Biomed Rep (2014) 2(2):270-4. doi:10.3892/ br.2014.217

44. Pawlotsky JM. New hepatitis C therapies: the toolbox, strategies, and challenges. Gastroenterology (2014) 146(5):1176-92. doi:10.1053/j.gastro.2014. 03.003

45. Werner JM, Serti E, Chepa-Lotrea X, Stoltzfus J, Ahlenstiel G, Noureddin M, et al. Ribavirin improves the IFN-gamma response of natural killer cells to IFNbased therapy of hepatitis C virus infection. Hepatology (2014) 60(4):1160-9. doi: $10.1002 /$ hep. 27092

46. Suarez-Ramirez JE, Tarrio ML, Kim K, Demers DA, Biron CA. CD8 T cells in innate immune responses: using STAT4-dependent but antigenindependent pathways to gamma interferon during viral infection. MBio (2014) 5(5):e1978-1914. doi:10.1128/mBio.01978-14

47. Su LF, Kidd BA, Han A, Kotzin JJ, Davis MM. Virus-specific CD4(+) memory-phenotype T cells are abundant in unexposed adults. Immunity (2013) 38(2):373-83. doi:10.1016/j.immuni.2012.10.021

48. Welsh RM, Che JW, Brehm MA, Selin LK. Heterologous immunity between viruses. Immunol Rev (2010) 235(1):244-66. doi:10.1111/j.0105-2896.2010. 00897.x

Conflict of Interest Statement: The authors declare the following conflicts of interest: Michael Peter Manns, Markus Cornberg, and Heiner Wedemeyer have received honoraria for consulting, speaking, and research support from Abbott Laboratories, Achillion Pharmaceuticals, AbbVie, Bristol Myer Squibb, Gilead Sciences, Janssen Pharmaceutica, Merck Serono KGaA, Novartis, and Roche Pharma AG. The remaining others have no conflict of interest to declare.

Copyright (c) 2015 Owusu Sekyere, Suneetha, Hardtke, Falk, Hengst, Manns, Cornberg, Wedemeyer and Schlaphoff. This is an open-access article distributed under the terms of the Creative Commons Attribution License (CC BY). The use, distribution or reproduction in other forums is permitted, provided the original author(s) or licensor are credited and that the original publication in this journal is cited, in accordance with accepted academic practice. No use, distribution or reproduction is permitted which does not comply with these terms. 